\title{
Diurnal Behavior of Sugarcane Acid Invertase in Early-Juvenile and Early-Adult Plants Treated with Polaris ${ }^{1}$
}

\author{
Alex G. Alexander ${ }^{2}$
}

\begin{abstract}
The diurnal behavior of sugarcane acid invertase was examined in 5- and 14-week old plants treated with Polaris (N,N-bis [phosphonomethyl] glycine). A commercial plant growth regulator and in vivo inhibitor of cane invertase, Polaris was administered as an aqueous foliar spray at $0645 \mathrm{~h}$. Immature stem samples were harvested at 2-h intervals from 0630 to $1830 \mathrm{~h}$ on day of treatment and throughout the following two days. In plantlets, Polaris produced a major shift in the time of maximum invertase action within $2 \mathrm{~h}$ after application and without inhibiting the enzyme. Polaris persistently inhibited invertase during the third day without distorting the time or magnitude of enzyme fluctuation. Similar effects were produced in young-adult plants having greatly lengthened and elaborated transport pathways. Neither the natural fluctuations nor chemical-induced changes were accompanied by changes in tissue sucrose, reducing sugars, or soluble protein. Results are discussed in the context of two control systems for acid invertase: one governing its synthesis in immature stem tissue and inhibited by Polaris, the other governing its diurnal behavior, possibly located in leaf tissues, and only temporarily distorted by Polaris.
\end{abstract}

\section{INTRODUCTION}

Activity levels for sugarcane acid invertase fluctuate several fold between early morning and late afternoon $(6,5,2)$. This capacity for rapid change is consonant with the enzyme's roles in storing and utilizing the large sucrose influxes received daily by sugarcane sink tissues (6, pp. 332-56, 11, 10). On the other hand, the regulatory system governing these changes, and the extent to which they are isolated from the general production of catalytic protein, are largely unknown.

The plant growth regulator Polaris ${ }^{3,4}$ is a very powerful and persistent in vivo inhibitor of sugarcane acid invertase $(2,3)$. As a chemical ripener, its maximum effect is usually recorded together with stem quality improvement several weeks or more after its application. As a physiological tool, however, it offers an insight into the invertase regulatory system by forcing the latter to respond to an imposed stress whose

${ }^{1}$ Manuscript submitted to the Editorial Board February 20, 1976.

${ }^{2}$ Plant Physiologist, Agricultural Experiment Station, University of Puerto Rico, Mayagüez Campus, Río Piedras, P.R.

${ }^{3}$ N,N-bis (phosphonomethyl) glycine. Monsanto Agricultural Products, Co., St. Louis, Mo.

${ }^{4}$ Trade names are used in this publication solely for the purpose of providing specific information. Mention of a trade name does not constitute a guarantee or warranty of equipment or materials by the Agricultural Experiment Station of the University of Puerto Rico or an endorsement over other equipment or materials not mentioned. 
timing and ultimate effects are known. For the present studies, Polaris was used as a stress-inducing agent in order to evaluate diurnal invertase behavior during a 3-day time course spanning the onset of chemical inhibition.

\section{MATERIALS AND METHODS}

Plants of the interspecific hybrid PR 980 were propagated in quartz sand with controlled water and nutrient regimes as previously described (4). Two experiments were performed, the first with 5-week old plantlets, and a second with young-adult plants 14 weeks old. In each experiment, expanding stem tissues were harvested for enzyme, sugar, and soluble protein analyses at $0630 \mathrm{~h}$ on day 0 , and at 2 -h intervals thereafter through $1830 \mathrm{~h}$. Samples were similarly harvested on the following two days (days 1 and 2).

Polaris was administered at $0645 \mathrm{~h}$ on day 0 , as an aqueous foliar spray containing $3000 \mathrm{p} / \mathrm{m}$ active material plus $0.10 \%$ Tween 20 as wetting agent. Control plants received distilled water plus wetting agent. There were three replications of each treatment arranged in an incomplete randomized block design.

Tissue samples were initially frozen in a mixture of dry ice and acetone. They were lyophilized, ground to a fine powder, and extracted with distilled water containing 2-mercapto-ethanol $(0.005 \mathrm{M})$ as a phenol oxidase inhibitor. Protein was precipitated with solid ammonium sulfate, redissolved in water, and dialyzed against a $0.001 \mathrm{M}$ solution of 2mercapto-ethanol. The protein obtained between 30 and 55 percent saturation was used for assay of acid invertase. Total soluble protein was determined with the 0 to 95 percent fraction. Sucrose and reducingsugar analyses were performed directly with clarified aqueous extracts. Procedures for the sugar, protein, and invertase assays are detailed in a previous report (4). Statistical comparisons of control and Polaris values at each harvest were performed in accordance with the Student $t$ test.

\section{RESULTS}

Maximum invertase activity in plantlets was shifted to an earlier hour by Polaris (fig. 1), and the effect was produced within two hours after chemical application. Repetition of the experiment with youngadult plants, i. e. in a vastly lengthened and elaborated source-to-sink system, produced a similar effect within four hours after application. Invertase repression became general during the third day of treatment for both experiments. Characteristic diurnal action patterns were retained in spite of Polaris repression of absolute activity. Neither the chemical-induced changes nor natural fluctuations for invertase were 


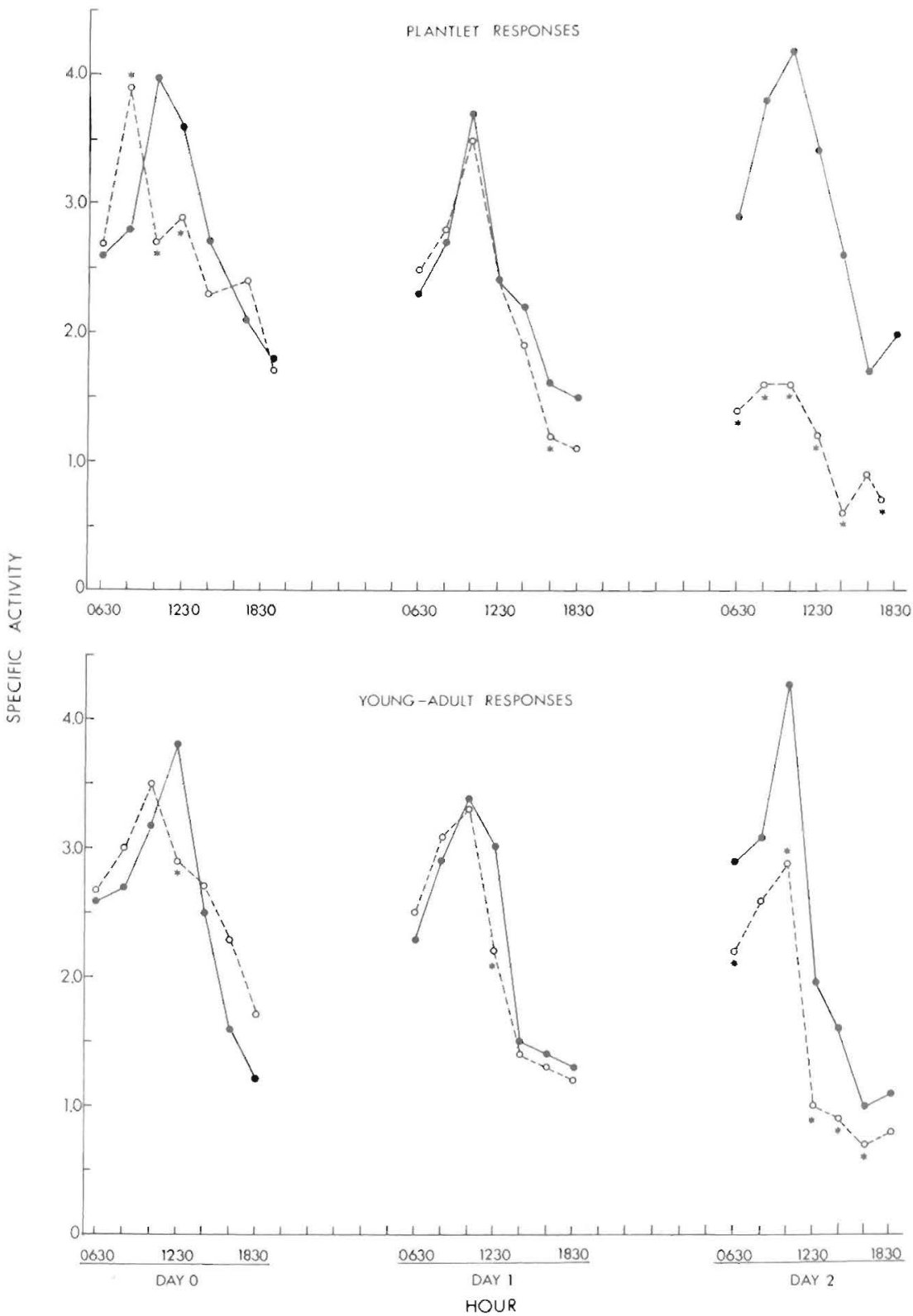

Fig. 1. - Diurnal behavior of sugarcane acid invertase in early-juvenile and earlyadult plants following treatment with Polaris. Symbols: ( - - Control; (-_ $\left.{ }_{--}\right)$Polaris. Asterisks indicate a significant deviation of Polaris values from the corresponding control values $(\mathrm{P}<.05)$. 
accompanied by similar changes in soluble protein, sucrose, or reducing: sugars (table 1).

\section{DISCUSSION}

While in general terms the endogenous levels of both substrate and product can affect the performance of a given enzyme, the present diurnal changes for acid invertase were not directly related to either factor. The rapidity and magnitude of change, and the concurrent lack of change in soluble protein, are consistent with the operation of a hormonal regulatory system specifically directed toward acid invertase. This interpretation for cane invertase regulation was developed by workers in Australia and has been reviewed in detail (6, pp. 359-82). On the other hand, the early distortion of peak activity by Polaris, plus the persistence of a diurnal fluctuation pattern after chemical repression was underway, offer several qualifications to prior understanding of invertase behavior.

The diurnal shift in maximum invertase activity, occurring within a few hours after Polaris application, suggests that the enzyme's change is governed by a timing system sensitive to the intrusion of a powerful growth regulator. The quickness of change in plantlets was at first considered to be an artifact of their abbreviated transport pathway, consisting only of 2 to 3 leaves closely connected with a miniature sink. If it is assumed that Polaris is translocated in cane via the phloem conducting pathway ${ }^{5}$ developed with ${ }^{14} \mathrm{C}$-labeled sucrose (6, pp. 274-88), at rate and velocity levels proportional to sucrose, traces of the chemical would begin to arrive at the plantlet sink about 40 minutes after leaf penetration. For young-adult plants the arrival of inhibitor at the apical meristem should require 2 to 3 hours $^{6}$. The bulk of transient Polaris would disperse along an extended sink, comprising 8 to 10 stem internodes of varying maturity, over a time course of about 24 hours. Repetition of the experiment with young-adult plants again produced an early distortion of maximum enzyme activity (fig. 1), indicating that the effect was not reliant upon an undeveloped transport pathway.

It can be argued that Polaris or a Polaris-induced inhibitor might be translocated more efficiently than sucrose. This is unlikely in view of

${ }^{5}$ There is evidence that the bipyridilium desiccant Diquat produces a reversal of metabolite transport from phloem to xylem conducting pathways in Lycopersicon (17); however, this appears to be an artifact of tissues approaching death and has not been reported with respect to chemical ripening.

${ }^{6}$ These estimates are based on a minimum transport pathway, that is from basal lamina tissue of the leaf blade having the shortest conducting distance to the apical meristem. 
TABLE 1.-Diurnal levels of expanding-stem tissue components of early-juvenile and early-adult sugarcane treated with Polaris

\begin{tabular}{|c|c|c|c|c|c|c|c|c|c|c|c|c|c|}
\hline \multirow{3}{*}{ Day } & \multirow{3}{*}{ Hour } & \multicolumn{6}{|c|}{ Early-juvenile components, mg/g- } & \multicolumn{6}{|c|}{ Early-adult components, mg/g - } \\
\hline & & \multicolumn{2}{|c|}{ Sucrose } & \multicolumn{2}{|c|}{ Total red. sugars } & \multicolumn{2}{|c|}{ Soluble protein } & \multicolumn{2}{|c|}{ Sucrose } & \multicolumn{2}{|c|}{ Total red. sugars } & \multicolumn{2}{|c|}{ Soluble protein } \\
\hline & & Control & Polaris ${ }^{1}$ & Control & Polaris & Control & Polaris & Control & Polaris & Control & Polaris & Control & Polaris \\
\hline \multirow[t]{7}{*}{0} & 0630 & 201 & 193 & 127 & 128 & 51 & 56 & 180 & 202 & 194 & 229 & 41 & 46 \\
\hline & 0830 & 215 & 162 & 146 & 142 & 59 & 59 & 207 & 193 & 226 & 227 & 48 & 44 \\
\hline & 1030 & 196 & 264 & 150 & 144 & 61 & 54 & 173 & 164 & 213 & 226 & 48 & 46 \\
\hline & 1230 & 234 & 259 & 149 & 136 & 42 & 41 & 197 & 207 & 229 & 220 & 38 & $49 *$ \\
\hline & 1430 & 220 & 233 & 134 & 125 & 55 & 48 & 233 & 241 & 209 & $241^{*}$ & 45 & 35 \\
\hline & 1630 & 205 & 230 & 169 & 170 & 59 & $42 *$ & 237 & 221 & 210 & 223 & 44 & 45 \\
\hline & 1830 & 240 & 236 & 125 & 139 & 43 & 42 & 235 & $208^{*}$ & 200 & 216 & 48 & 39 \\
\hline \multirow[t]{7}{*}{1} & 0630 & 193 & 175 & 145 & $116^{*}$ & 66 & 88 & 196 & 172 & 218 & 230 & 49 & 52 \\
\hline & 0830 & 183 & 152 & 142 & 137 & 95 & 90 & 175 & 154 & 239 & 245 & 45 & 42 \\
\hline & 1030 & 227 & 169 & 136 & 118 & 64 & 65 & 212 & 185 & 236 & 239 & 45 & 41 \\
\hline & 1230 & 217 & 209 & 131 & 122 & 72 & 72 & 240 & 260 & 229 & 235 & 37 & 45 \\
\hline & 1430 & 204 & 191 & 108 & 146 & 64 & 73 & 293 & 306 & 226 & 219 & 38 & 43 \\
\hline & 1630 & 198 & 221 & 124 & 107 & 80 & 67 & 278 & 268 & 220 & 227 & 41 & 46 \\
\hline & 1830 & 196 & 197 & 135 & 118 & 90 & 80 & 286 & 263 & 209 & 217 & 45 & 43 \\
\hline \multirow[t]{7}{*}{2} & 0630 & 134 & 159 & 109 & 91 & 39 & 46 & 199 & 200 & 198 & 198 & 45 & 45 \\
\hline & 0830 & 123 & $183^{* 2}$ & 101 & 88 & 44 & 38 & 202 & 197 & 210 & 206 & 51 & 47 \\
\hline & 1030 & 179 & 204 & 95 & 97 & 44 & 40 & 206 & 212 & 225 & 213 & 47 & 44 \\
\hline & 1230 & 187 & $275^{*}$ & 114 & $89^{*}$ & 44 & 36 & 249 & 257 & 217 & 200 & 38 & 54 \\
\hline & 1430 & 226 & $282^{*}$ & 107 & 88 & 33 & 30 & 277 & 275 & 212 & 192 & 36 & 42 \\
\hline & 1630 & 244 & 272 & 107 & 101 & 28 & 36 & 289 & 261 & 200 & 190 & 36 & 42 \\
\hline & 1830 & 193 & $286^{*}$ & 93 & 93 & 30 & 30 & 263 & 277 & 196 & 202 & 36 & 36 \\
\hline
\end{tabular}

1 Polaris was administered at $0645 \mathrm{~h}$ on day 0 , as an aqueous foliar spray containing $3000 \mathrm{p} / \mathrm{m}$ active ingredient.

${ }^{2}$ Asterisks indicate a significant deviation of the Polaris value from the corresponding control value $(\mathrm{P}<.05)$. 
TABLE 2.-Acid invertase activity over a three-day time course in early-juvenile and earlyadult sugarcane treated with Polaris

\begin{tabular}{|c|c|c|c|c|c|c|}
\hline \multirow{3}{*}{$\begin{array}{l}\text { Plant age } \\
\text { (weeks) }\end{array}$} & \multicolumn{6}{|c|}{ Average specific activity ${ }^{1}$ values, for day - } \\
\hline & \multicolumn{2}{|c|}{0} & \multicolumn{2}{|c|}{1} & \multicolumn{2}{|c|}{2} \\
\hline & Control & Polaris & Control & Polaris & Control & Polaris \\
\hline 5 & 2.8 & 2.7 & 2.3 & 2.2 & 2.9 & 1.1 \\
\hline 14 & 2.5 & 2.7 & 2.3 & 2.1 & 2.3 & 1.5 \\
\hline \multicolumn{7}{|c|}{ Daily max. activity/Daily min. activity } \\
\hline 5 & 2.2 & 2.3 & 2.5 & 3.1 & 2.5 & 2.7 \\
\hline 14 & 3.2 & 2.1 & 2.6 & 2.8 & 3.9 & 4.1 \\
\hline
\end{tabular}

${ }^{1}$ Specific activity = activity units/mg of protein. One activity unit equalled the amount of enzyme required to produce $0.10 \mathrm{mg}$ of reducing sugar under the prescribed conditions of the assay (4).

the complex anatomy of sugarcane conducting tissues, and of transport logistics in a conduit system already burdened with sucrose $(6, \mathrm{pp} .321-$ 26). A more plausible interpretation is that small amounts of Polaris had confounded an endogenous timing or "clock" mechanism governing the diurnal pattern for invertase activity. Moreover, this mechanism might be located in leaf tissues where translocation time is not a decisive factor. The main support for this hypothesis derives from the rapidity of the early changes effected by Polaris, and the fact that these were not changes in absolute activity (table 2), but rather in the timing of maximum activity. The traditional Polaris repression was not clearly underway until the third day (fig. 1, table 2).

The hypothetical timing mechanism for invertase is apparently not damaged or permanently distorted by Polaris. Invertase changes recorded shortly after the chemical's application were not repeated during the second day, nor during the third day when activity repression in sink tissue was clearly underway ${ }^{7}$ (fig. 1). At this time the magnitude of diurnal flucuation in Polaris-treated plants remained proportionately equal to the fluctuation in control plants (table 2). This is interpreted in terms of a net loss of invertase-producing capability-presumably a Polaris restriction of invertase m-RNA $(9,15)$ - while a second system governing the diurnal conformation of the enzyme's remaining work potential continues to operate unimpeded. The continued operation of a diurnal control system is also consistent with the view that some critical level of invertase activity must continue in support of sucrose accumulation processes, even while sucrose inversion for support of growth and respiratory processes is being curtailed.

\footnotetext{
${ }^{7}$ Presumably, most of the Polaris that penetrated the cane canopy would have exited leaf tissues by the second day.
} 
Hormone-like substances having powerful regulatory effects on plant source and sink processes that are spatially removed from the site of substance production are generally recognized and have been discussed by numerous authors $(13,8,12,14,7)$. The concept of foliar contributions toward the invertase changes presently recorded in sink tissues is empirically consonant with earlier findings from variable-illumination studies $(5,1)$. However, the operation of a foliar "clock" for invertase remains a matter of speculation. Polaris, thoughtfully utilized, will serve as a useful tool in examining source regulation of sink reactions.

\section{RESUMEN}

Se examinó el comportamiento diurno de la invertasa ácida en plantas de cana de azúcar de 5 y 14 semanas de edad tratadas con Polaris. Este se administró en aspersión foliar acuosa a las $0645 \mathrm{~h}$. Se cosecharon muestras de tallos verdes a intervalos de 2 horas de 0630 a $1830 \mathrm{~h}$ el día del tratamiento y durante los dos dias siguientes. En las plántulas, Polaris adelantó el tiempo de acción máxima de la invertasa dentro de las 2 horas posteriores a la aplicación, sin retardar la acción de la enzima. Durante el tercer dia Polaris retardó persistentemente la invertasa sin alterar el tiempo o la magnitud de fluctuación de la enzima. Efectos similares se produjeron en plantas adultas jóvenes con conductos de transporte alargados y elaborados. Ni las fluctuaciones naturales ni los cambios producidos por el agente químico fueron acompañados por cambios en el contenido de sacarosa del tejido, reducción de los azúcares o cantidad de proteína soluble. En este contexto se discuten dos sistemas de control para la invertasa ácida, uno que gobierna su sintesis y el otro que gobierna su comportamiento diurno, posiblemente localizado en los tejidos de la hoja, el que el Polaris altera temporalmente.

\section{LITERATURE CITED}

1. Alexander, A. G., Kumer, A., Montalvo-Zapata, R., and Spain, G. L., Response of sugarcane to variable light: Variable illumination studies of invertase, ATP-ase and amylase in plants experiencing nitrate- and gibberellic acid-induced stress, $J$. Agr. Univ. P.R. 54(3): 448-76, 1970.

2. Alexander, A. G., and Montalvo-Zapata, R., Ripening activity of CP 41845 in sugarcane having nitrate- and gibberellic acid-stimulated growth regimes, Crop Sci. 12: $654-7,1972$.

3. - and - Studies on the activity of CP 41845 in early-juvenile sugarcane, Crop Sci. 12: 677-80, 1972.

4. - and - Evaluation of chemical ripeners for sugarcane having constant nitrogen and moisture regimes. I. Growth, quality, and enzymic responses of nine potential ripeners, Tropical Agr. (Trinidad) 50(1): 35-44, 1973.

5. - - - and Justiniano, M. G., Diurnal behavior of sugarcane acid invertase, J. Agr. Univ. P.R. 57(1): 84-6, 1973

6. Alexander, A. G., Sugarcane Physiology. A Comprehensive Study of the Saccharum Source-to-Sink System, Elsevier Scientific Publishing Co., Amsterdam, 1973: 33256.

7. Audus, L. J., Plant Growth Substances, 3rd ed, Vol. 1, Barnes \& Noble Books, New York, 1972

8. Beevers, H., Metabolic sinks, Chap, 8 in: Physiological Aspects of Crop Yield, J. D. Eastin (Editorial Chairman), American Society of Agronomy, Madison, Wiscon$\sin , 1969$.

9. Gayler, K. R., and Glasziou, K. T., Plant enzyme synthesis: Hormonal regulation of invertase and peroxidase synthesis in sugarcane, Planta 84: 185-94, 1969. 
10. Glasziou, K. T., and Bull, T. A., The relation between total invertase activity and internode expansion in sugarcane stalks, Proc. Int. Soc. Sugar Cane Technol. 12: 575-81, 1967.

11. Hatch, M. D., Sacher, J. A., and Glasziou, K. T., Sugar accumulation cycle in sugarcane. I. Studies on enzymes of the cycle, Plant Physiol. 38(3): 338-43, 1964.

12. Leopold, C. A., Plant Growth and Development (2nd ed), McGraw-Hill Book Company, New York, 1974.

13. Leshem, Y., The Molecular and Hormonal Basis of Plant Growth Regulation, Pergamon Press, Oxford, 1973.

14. Plant Growth Substances 1970, Proceedings of the 7th International Conference on Plant Growth Substances, Canberra, 1970. D. J. Carr (Ed), Springer-Verlag (Publishers), 1972.

15. Sacher, J. A., and Glasziou, K. T., Regulation of invertase levels in sugarcane by an auxin-carbohydrate mediated control system, Biochem. Biophys. Res. Commun. 8(4): 280-2, 1962.

16. Slack, C. R., The physiology of sugarcane. VIII. Diurnal fluctuations in the activity of soluble invertase in elongating internodes, Aust. J. Biol. Sci. 18: 781-8, 1965.

17. Smith, J. M., and Sagar, G. R., A re-examination of the influence of light and darkness on the long-distance transport of Diquat in Lycopersicon esculentum Mill., Weed Res. 6: 314-21, 1966. 